\title{
Melatonin increases growth and salt tolerance of Limonium bicolor by improving photosynthetic and antioxidant capacity
}

\author{
Junpeng $\mathrm{Li}^{1 \dagger}$, Yun Liu ${ }^{1 \dagger}$, Mingjing Zhang ${ }^{1 \dagger}$, Hualing $\mathrm{Xu}^{2}$, Kai Ning ${ }^{2}$, Baoshan Wang ${ }^{1 *}$ and Min Chen ${ }^{1 *}$
}

\begin{abstract}
Background: Soil salinization is becoming an increasingly serious problem worldwide, resulting in cultivated land loss and desertification, as well as having a serious impact on agriculture and the economy. The indoleamine melatonin (N-acetyl-5-methoxytryptamine) has a wide array of biological roles in plants, including acting as an auxin analog and an antioxidant. Previous studies have shown that exogenous melatonin application alleviates the saltinduced growth inhibition in non-halophyte plants; however, to our knowledge, melatonin effects have not been examined on halophytes, and it is unclear whether melatonin provides similar protection to salt-exposed halophytic plants.

Results: We exposed the halophyte Limonium bicolor to salt stress $(300 \mathrm{mM})$ and concomitantly treated the plants with $5 \mu \mathrm{M}$ melatonin to examine the effect of melatonin on salt tolerance. Exogenous melatonin treatment promoted the growth of L. bicolor under salt stress, as reflected by increasing its fresh weight and leaf area. This increased growth was caused by an increase in net photosynthetic rate and water use efficiency. Treatment of salt-stressed L. bicolor seedlings with $5 \mu \mathrm{M}$ melatonin also enhanced the activities of antioxidants (superoxide dismutase [SOD], peroxidase $[P O D]$, catalase [CAT], and ascorbate peroxidase [APX]), while significantly decreasing the contents of hydrogen peroxide $\left(\mathrm{H}_{2} \mathrm{O}_{2}\right)$, superoxide anion $\left(\mathrm{O}_{2}^{-}{ }^{-}\right)$, and malondialdehyde (MDA). To screen for L. bicolor genes involved in the above physiological processes, high-throughput RNA sequencing was conducted. A gene ontology enrichment analysis indicated that genes related to photosynthesis, reactive oxygen species scavenging, the auxin-dependent signaling pathway and mitogen-activated protein kinase (MAPK) were highly expressed under melatonin treatment. These data indicated that melatonin improved photosynthesis, decreased reactive oxygen species (ROS) and activated MAPK-mediated antioxidant responses, triggering a downstream MAPK cascade that upregulated the expression of antioxidant-related genes. Thus, melatonin improves the salt tolerance of L. bicolor by increasing photosynthesis and improving cellular redox homeostasis under salt stress.
\end{abstract}

Conclusions: Our results showed that melatonin can upregulate the expression of genes related to photosynthesis, reactive oxygen species scavenging and mitogen-activated protein kinase (MAPK) of L. bicolor under salt stress, which

\footnotetext{
*Correspondence: bswang@sdnu.edu.cn; chenminrundong@126.com †Junpeng Li , Yun Liu and Mingjing Zhang these authors contributed equally to this work.

1 Shandong Provincial Key Laboratory of Plant Stress Research, College of Life Sciences, Shandong Normal University, Jinan, Shandong 250014 , People's Republic of China

Full list of author information is available at the end of the article
} original author(s) and the source, provide a link to the Creative Commons licence, and indicate if changes were made. The images or other third party material in this article are included in the article's Creative Commons licence, unless indicated otherwise in a credit line to the material. If material is not included in the article's Creative Commons licence and your intended use is not permitted by statutory regulation or exceeds the permitted use, you will need to obtain permission directly from the copyright holder. To view a copy of this licence, visit http://creativecommons.org/licenses/by/4.0/. The Creative Commons Public Domain Dedication waiver (http://creativeco mmons.org/publicdomain/zero/1.0/) applies to the data made available in this article, unless otherwise stated in a credit line to the data. 
can improve photosynthesis and antioxidant enzyme activities. Thus melatonin can promote the growth of the species and maintain the homeostasis of reactive oxygen species to alleviate salt stress.

Keywords: Antioxidant, Gene expression, Limonium bicolor, Melatonin, Salt tolerance

\section{Background}

Biotic and abiotic stresses severely inhibit plant growth and development $[38,52]$. Among these stressors, soil salinization is becoming an increasingly serious problem worldwide, causing cultivated land loss and desertification and seriously impacting agriculture and the economy $[10,17,18,36]$. Some plants such as halophytes with high salt tolerance can survive in saline soils being higher or equal to $200 \mathrm{mM} \mathrm{NaCl}$, which can increase the use of saline land and even improve it [7, $11,31,32,41]$. Salt stress causes not only osmotic and ionic stresses, but also oxidative stress, which inhibits photosynthesis, nutrient use, protein synthesis, and enzyme activity $[8,17,18,37]$. Moreover, oxidative stress caused by high salt stress leads to the accumulation of large amounts of reactive oxygen species (ROS), such as hydrogen peroxide $\left(\mathrm{H}_{2} \mathrm{O}_{2}\right)$ and superoxide anion $\left(\mathrm{O}_{2}{ }^{\cdot-}\right)$ $[25,40]$. The excessive ROS inhibit photosynthesis, respiration, and protein synthesis and disrupt membrane structure, etc. [16, 19, 35], thereby inhibiting growth and, in severe cases, causing death. To overcome oxidative stress, plants can upregulate antioxidative enzymes activities and increase nonenzymatic antioxidants levels [25]. The antioxidative enzymes in plants consist mainly of superoxide dismutase (SOD), peroxidase (POD), catalase (CAT), and ascorbate peroxidase (APX) (Apel et al. 2004 [28];). In addition, low level of ROS act as second messengers that activate stress-related regulators, such as mitogen-activated protein kinase (MAPK) and transcription factors, which activate the expression of stressrelated genes and enhance plant tolerance [15]. The activation of a plant's antioxidant system under adverse conditions helps the plant maintain its normal life activities and increases its tolerance to stress.

Photosynthesis, the plant's source of energy and fixed carbon, consists of light and dark reactions [8]. Salt stress decreases the supply of $\mathrm{CO}_{2}$ and inhibits the activity of enzymes involved in the dark reactions, which diverts excess light energy from the light reactions into ROS production $[15,26]$. Excessive ROS in turn disrupt thylakoid membrane structure and reduce the activity of light reaction enzymes, resulting in a decline in photosynthesis. Therefore, the timely removal of ROS produced under salt stress is essential for the maintenance and restoration of photosynthesis.

Melatonin (N-acetyl-5-methoxytryptamine) was first identified in animals, where it regulates circadian sleep rhythms [20] and the immune system $[1,50]$ and increases the activities of antioxidant enzymes [34]. Melatonin has multiple physiological functions in regulating plant growth and developmental processes, such as melatonin significantly enhanced the numbers of adventitious roots of Solanum lycopersicum [47], delayed leaves senescence of apple [46] etc. In addition, studies have shown that melatonin can increase plant resistance to various stresses. Liu et al. [27] showed that SlCOMT1, a melatonin biosynthesis-related gene from tomato (Solanum lycopersicum Mill. cv. Ailsa Craig), overexpression transgenic tomato plants had higher melatonin content than wild-type plants, which can improve SlCOMT1 overexpression plants resistance to salt stress. Zhu et al. [57] showed that exogenous melatonin significantly improved Arabidopsis thaliana resistance to Botrytis cinerea infection by enhancing activities of antioxidative enzymes and maintaining intracellular $\mathrm{H}_{2} \mathrm{O}_{2}$ concentrations at steady-state levels. Salt stress inhibit the growth of Alfalfa (Medicago sativa L.) and melatonin significantly alleviated this growth inhibition by reducing ROS content [2]. Under salt stress, melatonin can induce lateral root formation of cucumber (Cucumis sativus L.) seedlings and RNA sequencing showed that peroxidase-related genes to be involved in the melatonin response [56]. Sun et al. [42] showed that overexpression of COMT1 (Caffeic Acid O-Methyltransferase 1) in tomato (Solanum lycopersicum) significantly increased melatonin level and salt stress tolerance of transgenic lines by improving antioxidant capacity. Although some studies report that melatonin enhances the salt tolerance of glycophytes [2, 42, 57], to the best of our knowledge, studies on melatonin-induced salt tolerance of halophyte are elusive.

Halophyte can grow well in moderately saline soil while whose growth is inhibited under high salt stress. Limonium bicolor is a typical secretohalophyte with epidermal salt glands. This species grows best under moderately salty conditions $(100 \mathrm{mM} \mathrm{NaCl})$, but its growth is inhibited by high salt stress $[9,53]$. L. bicolor is used in traditional Chinese medicine and has excellent medicinal value for treating blood disorders, heat-evil, hepatitis, diarrhea, bronchitis, emmeniopathy, uterine cancer, and other diseases ( $\mathrm{Li}$ 1978). However, the growth inhibition of L. bicolor under high salt conditions has restricted the effective use and development of the species. Our previous 


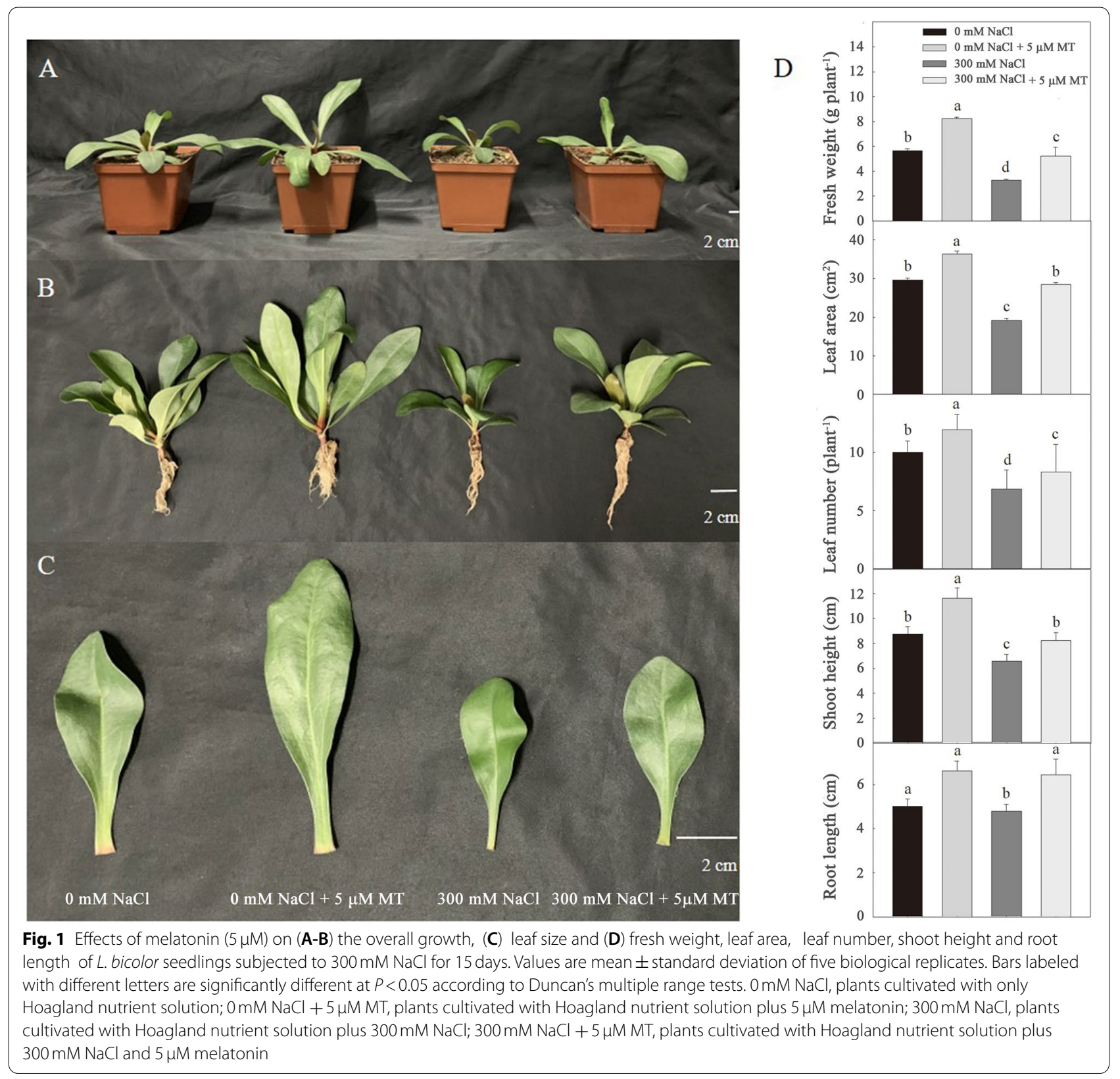

results showed that exogenous melatonin can improve the growth of $L$. bicolor under salt stress by increasing salt secretion capacity of salt gland [24]. In addition to increasing its salt secreting ability, whether exogenous melatonin can be through other ways to relieve the high salt stress of the species? In this study, we examined the effect of exogenous melatonin on growth, photosynthesis, and antioxidant enzyme activity in $L$. bicolor. These results provide a basis for further studying the melatonin response mechanism of plants, especially of halophytes under salt stress.

\section{Results}

Melatonin promotes $L$. bicolor growth under salt stress

Salt stress $(300 \mathrm{mM} \mathrm{NaCl})$ retarded growth rate of $L$. bicolor seedlings, as evidenced by the reduction of fresh weight, shoot height, root length (Fig. 1A, B and D), leaf area (Fig. 1C, D) and the number of leaves (Fig. 1D). Exogenous melatonin treatment $(5 \mu \mathrm{M})$ improved the growth of $L$. bicolor seedlings, resulting in a greater fresh weight and leaf area, higher shoot height, longer root length and more leaves than those of control seedlings, regardless of whether the seedlings were treated with 
$0 \mathrm{mM}$ or $300 \mathrm{mM} \mathrm{NaCl}$ (Fig. 1). After 15 days of treatment, seedlings treated with exogenous melatonin and $0 \mathrm{mM} \mathrm{NaCl}$ had a fresh weight that was $49.1 \%$ greater than that of untreated control seedlings, whereas those treated with both melatonin and $300 \mathrm{mM} \mathrm{NaCl}$ had a fresh weigh that was $64.5 \%$ greater than that of seedlings treated with $300 \mathrm{mM} \mathrm{NaCl}$ only.

\section{Melatonin increases chlorophyll content and photosynthesis of $L$. bicolor under salt stress}

L. bicolor seedlings treated with salt for 15 days had considerably lower transpiration rates (Tr, Fig. 2A), stomatal conductance ( $g_{s}$, Fig. 2B), net photosynthetic rate (Pn, Fig. 2C), intercellular carbon dioxide concentration (Ci, Fig. 2D), intrinsic water use efficiency (WUEint, Fig. 2E) and instantaneous wawter use efficiency (WUEins, Fig. 2F) than untreated controls. Application of exogenous melatonin for 15 days led to significantly increased $\mathrm{Tr}, \mathrm{g}_{\mathrm{s}}, \mathrm{Pn}$, WUEint and WUEins in both $\mathrm{NaCl}$-treated and untreated plants.

Total chlorophyll, chlorophyll a, and chlorophyll b (Fig. 2G) contents of L. bicolor seedlings significantly increased under treatment with $300 \mathrm{mM} \mathrm{NaCl}$ compared to those of controls. Total chlorophyll and chlorophyll a contents increased even further in salt-stressed plants treated with exogenous melatonin.

\section{Melatonin reduces oxidative stress in L. bicolor under salt stress}

The ROS produced under salt stress consist mainly of $\mathrm{H}_{2} \mathrm{O}_{2}$ and $\mathrm{O}_{2}{ }^{\cdot-}$. The $\mathrm{H}_{2} \mathrm{O}_{2}$ and $\mathrm{O}_{2}{ }^{--}$levels in the $L$. bicolor seedlings significantly increased under salt stress, whereas melatonin treatment significantly attenuated these increases (Fig. 3A). Similarly, MDA content, which reflects the degree of cell membrane damage, significantly increased under $\mathrm{NaCl}$ stress, whereas melatonin treatment significantly decreased MDA content in the salt-stressed seedlings (Fig. 3A).

\section{Melatonin increases the activities of antioxidant enzymes in L. bicolor under salt stress}

Plants have developed antioxidant systems that remove ROS and help prevent the cellular damage induced by excess ROS under unfavorable conditions. Antioxidant enzymes play an important role in removing excess ROS. A $300 \mathrm{mM} \mathrm{NaCl}$ treatment significantly increased SOD activity, decreased the activities of POD and CAT, and had no significant effect on APX activity (Fig. 3B) in $L$. bicolor seedlings. However, exogenous melatonin treatment significantly increased SOD (increased by $14.3 \%$ ), POD (42.9\%), CAT (25.0\%), and APX (8.6\%) activities compared to salt-stressed seedlings without melatonin.

\section{Melatonin upregulates the expression of genes related to photosynthesis and reactive oxygen species scavenging in L. bicolor under salt stress}

To investigate the mechanism underlying melatonininduced $\mathrm{NaCl}$ stress tolerance in L. bicolor seedlings, dynamic profiling of the mRNA expression was obtained via transcriptome sequencing. Totally, 520 (256 upregulated genes and 264 downregulated genes), 2883 (1571 upregulated genes and 1312 downregulated genes), 2711 (1501 upregulated genes and 1206 downregulated genes) and 498 (297 upregulated genes and 201 downregulated genes) differently expressed genes (DEGs) were separately identified in contrastive groups of 'B2 vs. B1,' $\mathrm{B} 3$ vs. B1', 'B4 vs. B1' and 'B4 vs. B3' (Fig. 4). Most numbers of DEGs were shown in $\mathrm{NaCl}$ vs. control, which involved in ions transporters and salt secretion from the salt gland and had been confirmed before (Li et l., 2020). About 500 DEGs were shown in 'melatonin vs. control' or 'melatonin $+\mathrm{NaCl}$ vs. $\mathrm{NaCl}$ ', which suggested that melatonin may involve in regulating genes expression in L. bicolor. Venn diagram analysis showed that 83 DEGs were influenced by melatonin under both control and $\mathrm{NaCl}$ stress conditions (the intersection of "B2 vs. B1" and 'B4 vs. B3'), which implied that these genes might be involved in melatonin-induced $\mathrm{NaCl}$ stress tolerance.

Most of the 83 DEGs influenced by melatonin under both control and $\mathrm{NaCl}$ involved in photosynthesis, reactive oxygen species scavenging, IAA (indoleacetic acid) function and ion transport in L. bicolor (Table 1). To validate the correlation between the RNA-seq and qRT-PCR results, we designed 14 pairs of primers (Table S1) to target the DE gene transcripts. The tested genes encode proteins that are involved in photosynthesis, ROS scavenging system and ion transport. The results from the RNA-seq and qRT-PCR showed that the correlation between the transcriptome sequencing and qRT-PCR values was high $\left(\mathrm{R}^{2}=0.81\right.$, Fig. 5).

Go (gene ontology) analysis showed that melatonin upregulated the genes expression related to MAPK signaling pathways, photosynthetic structure and membrane, ion channels or transporters and some metabolic process etc. under salt stress (Fig. S1). In the upregulated genes, MAPK3 expression

(See figure on next page.)

Fig. 2 Effects of melatonin $(5 \mu \mathrm{M})$ on $(\mathbf{A})$ transpiration rate $(\mathrm{Tr}),(\mathbf{B})$ stomatal conductance $\left(\mathrm{g}_{\mathrm{s}}\right),(\mathbf{C})$ net photosynthetic rate $(\mathrm{Pn}),(\mathbf{D})$ inter cellular CO${ }_{2}$ concentration (Ci), (E) intrinsic water use efficiency (WUEint), (F) instantaneous water use efficiency (WUEins), (G) total chlorophyll, chlorophyll a, chlorophyll b content of L. bicolor seedlings subjected to $300 \mathrm{mM} \mathrm{NaCl}$ for 15 days. Values are mean \pm standard deviation of five biological replicates. Bars labeled with different letters are significantly different at $P<0.05$ according to Duncan's multiple range tests. Chl, Chlorophyll 
A

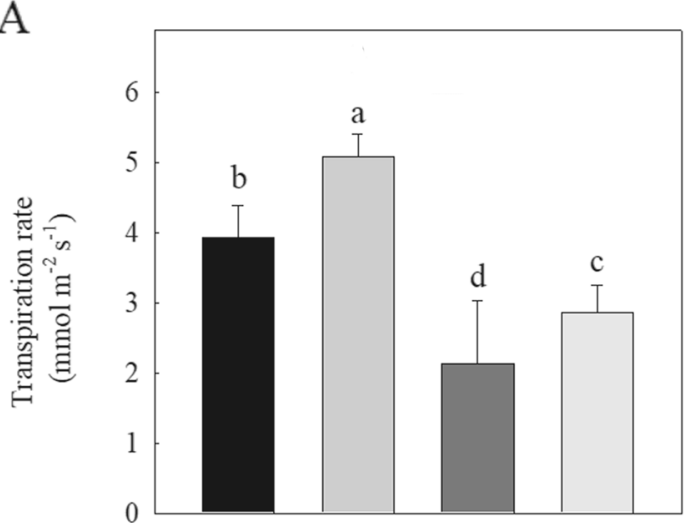

C

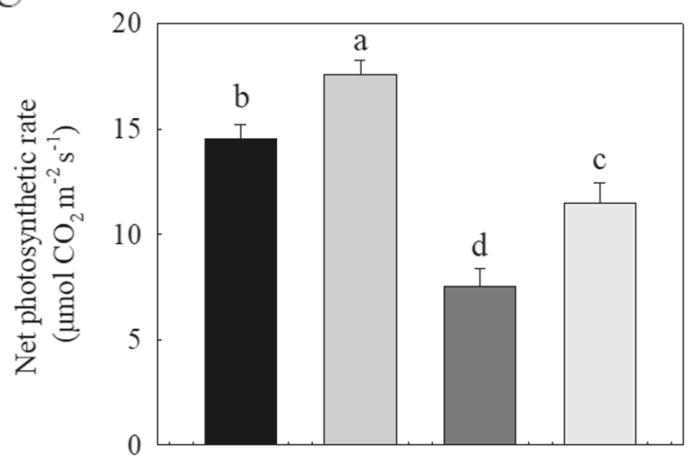

E

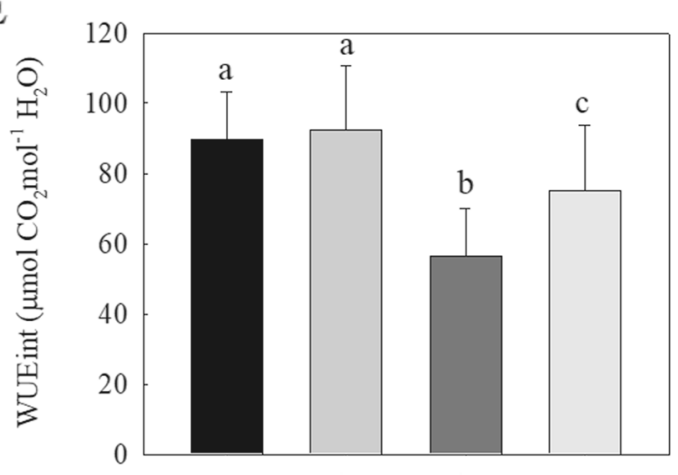

B
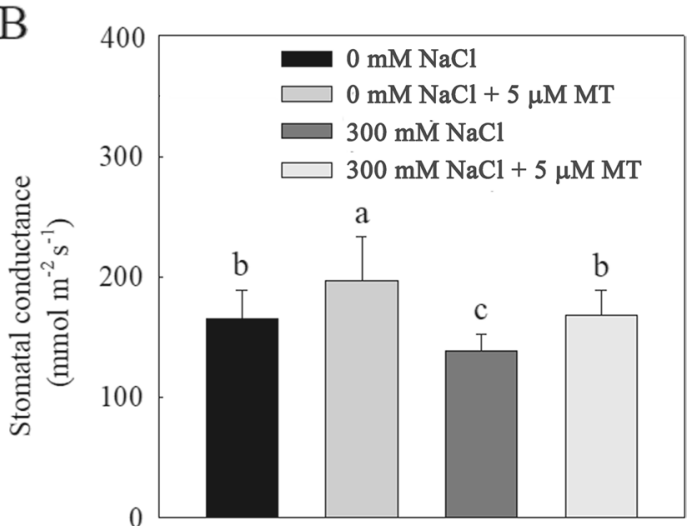

D

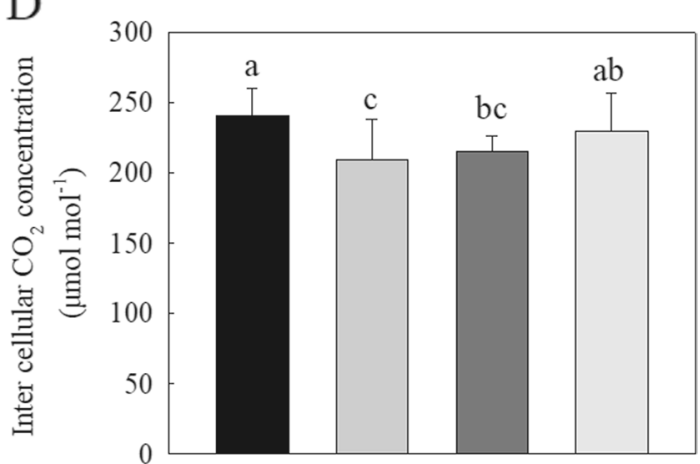

F

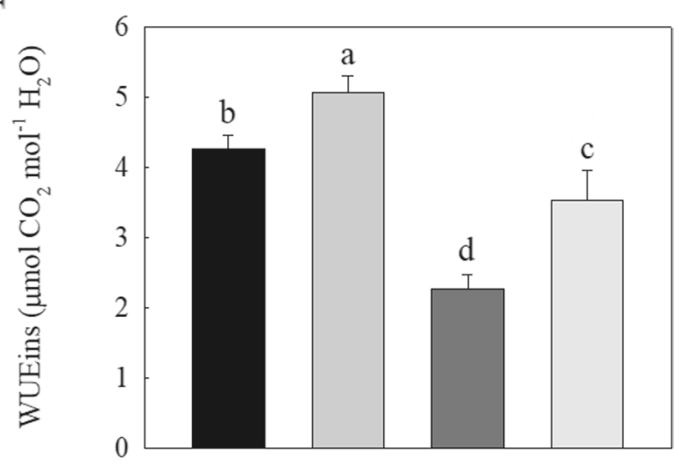

G

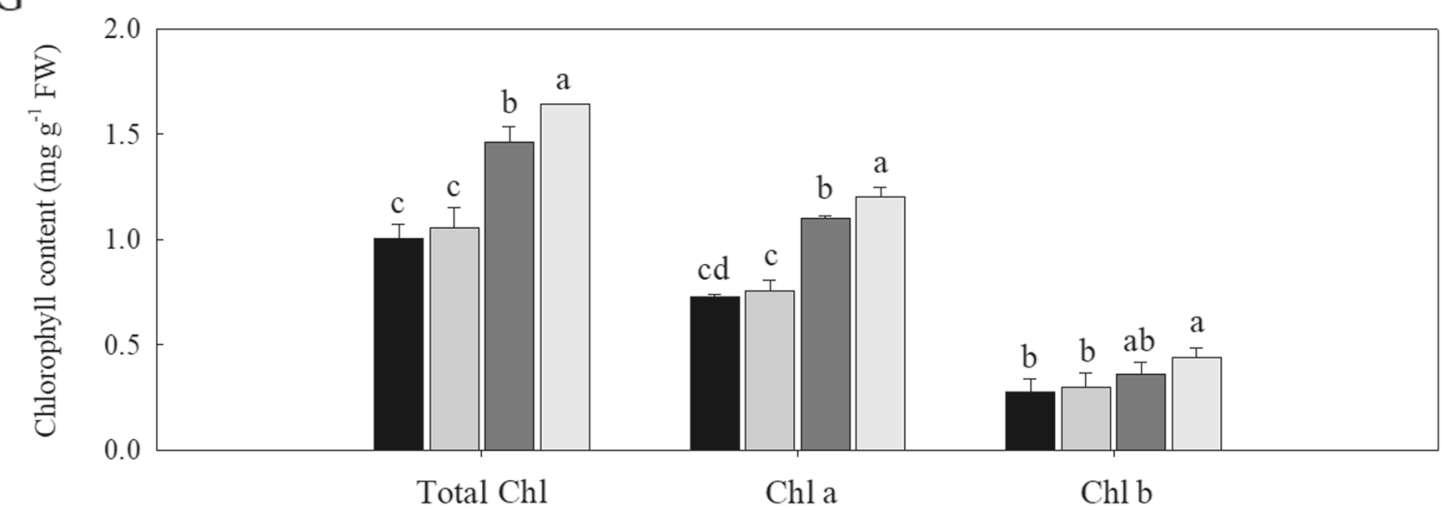

Fig. 2 (See legend on previous page.) 

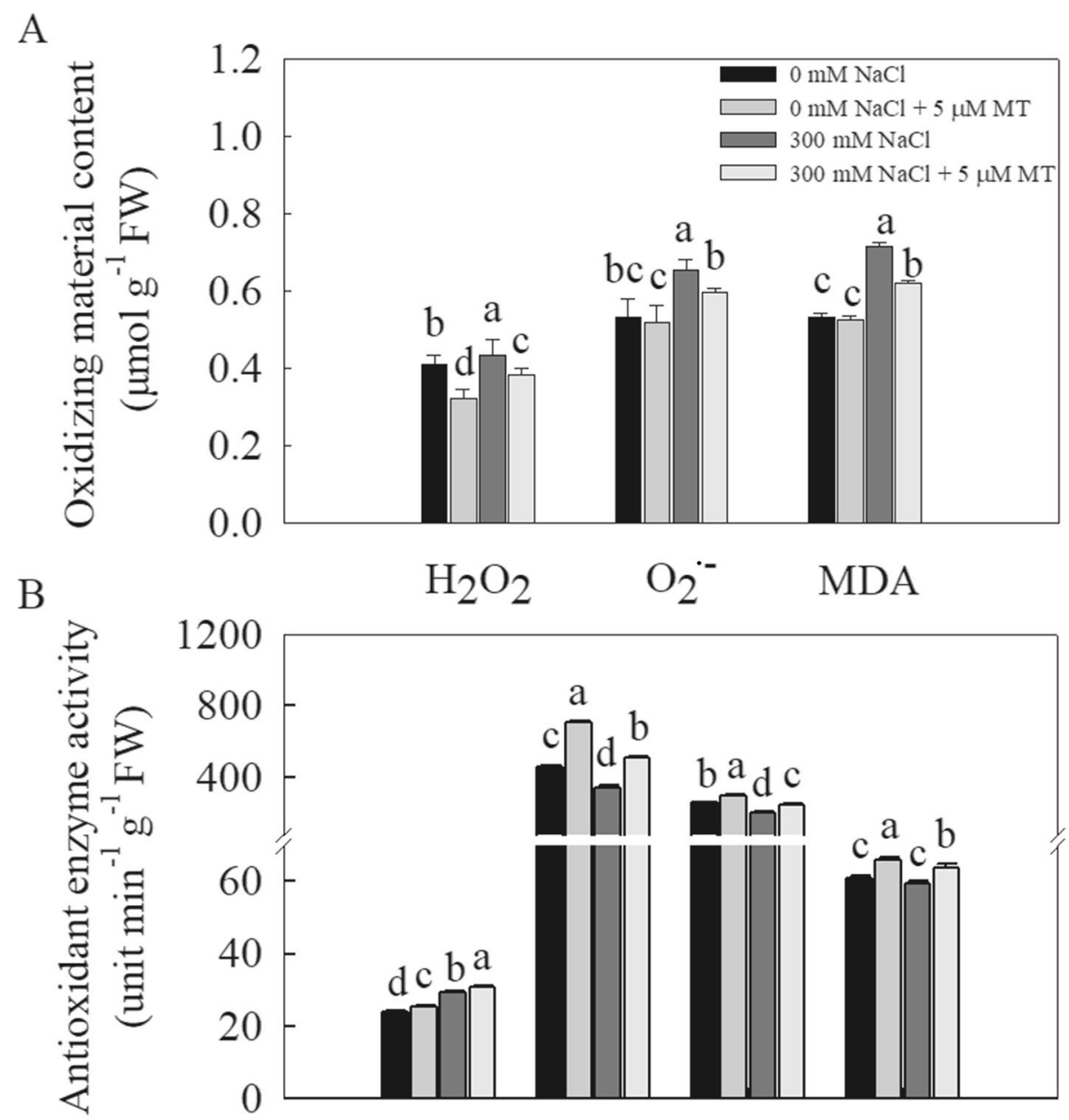

\section{0}

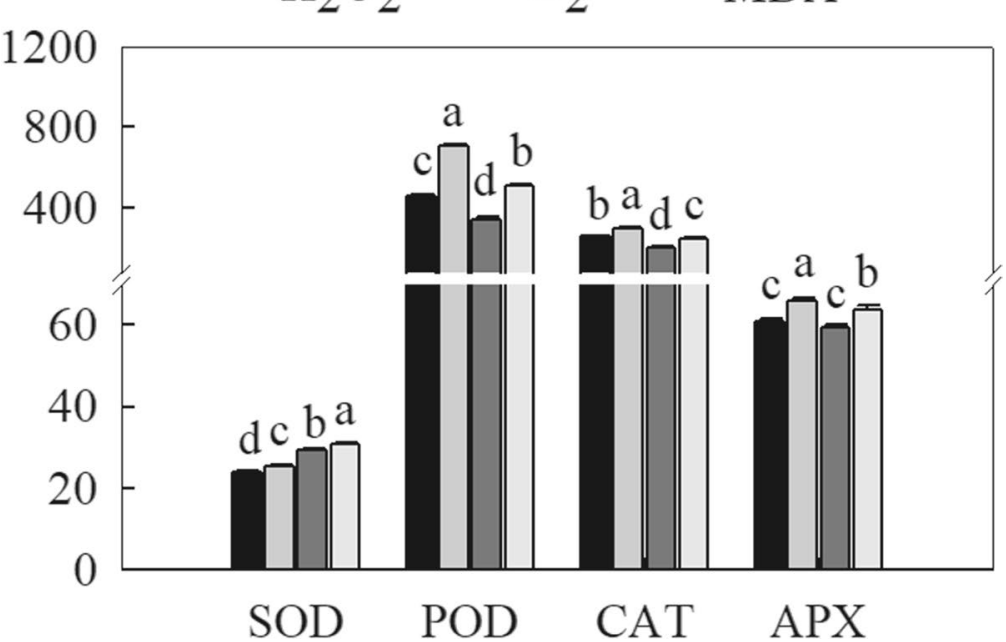

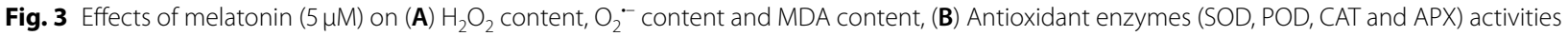
of $L$. bicolor seedlings subjected to $300 \mathrm{mM} \mathrm{NaCl}$ for 15 days. Values are mean \pm standard deviation of five biological replicates. Bars labeled with different letters are significantly different at $P<0.05$ according to Duncan's multiple range tests. $0 \mathrm{mM} \mathrm{NaCl}$, plants cultivated with only Hoagland nutrient solution; $0 \mathrm{mM} \mathrm{NaCl}+5 \mu \mathrm{M}$ MT, plants cultivated with Hoagland nutrient solution plus $5 \mu \mathrm{M}$ melatonin; $300 \mathrm{mM} \mathrm{NaCl}$, plants cultivated with Hoagland nutrient solution plus $300 \mathrm{mM} \mathrm{NaCl} ; 300 \mathrm{mM} \mathrm{NaCl}+5 \mu \mathrm{M} \mathrm{MT}$, plants cultivated with Hoagland nutrient solution plus $300 \mathrm{mM} \mathrm{NaCl}$ and $5 \mu \mathrm{M}$ melatonin

was examined under melatonin and salt treatment in the species. The results showed that $300 \mathrm{mM} \mathrm{NaCl}$ treatment for 24-72 h significantly upregulated the gene expression, while melatonin treatment for $12-72 \mathrm{~h}$ significantly upregulated the gene expression regardless of whether the seedlings were treated not or with $300 \mathrm{mM} \mathrm{NaCl}$. Compared to the control, the gene expression upregulated 4.6 times under melatonin treatment for $12 \mathrm{~h}$, while 6.7 times under melatonin and $300 \mathrm{mM} \mathrm{NaCl}$ treatment for $24 \mathrm{~h}$ (Fig. 6).

\section{Discussion}

Melatonin has received increasing attention in studies of plant stress tolerance [3, 39]. Previous studies showed that exogenous melatonin application can alleviate salt-induced growth inhibition in some non-halophytes, such as watermelon (Citrullus lanatus) and cucumber [22, 45, 49]. However, whether exogenous melatonin treatment can alleviate salt-induced growth inhibition in halophytes was rarely reported. Our previous results showed that exogenous melatonin can increase salt secretion from salt glands of secretohalophyte L. bicolor, decrease the content of $\mathrm{Na}^{+}$and $\mathrm{Cl}^{-}$in leaves to alleviate $\mathrm{NaCl}$ stress [24]. Whether melatonin alleviate $\mathrm{NaCl}$ induced growth inhibition to the species through other ways? In this study, we treated $L$. bicolor seedlings with salt and melatonin and showed that $5 \mu \mathrm{M}$ melatonin promotes plant growth under salt stress, increasing the fresh weight and leaf area of the treated plants (Fig. 1). 

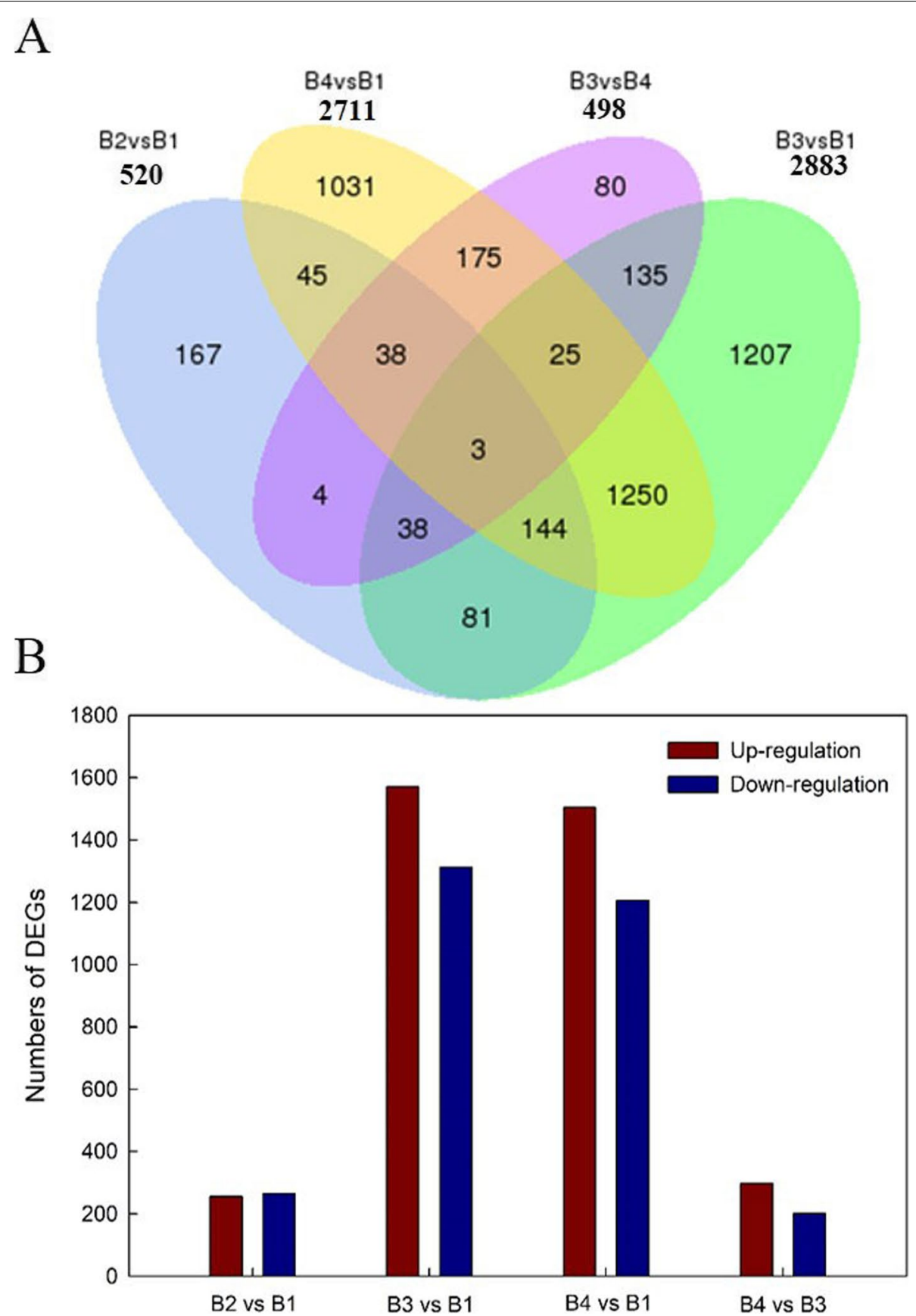

Fig. 4 Effects of melatonin ( $5 \mu \mathrm{M}$ ) on genes expression of L. bicolor seedlings subjected to $300 \mathrm{mM} \mathrm{NaCl}$ for $24 \mathrm{~h}$. (A) Venn diagram showing numbers of overlapping DEGs in the transcriptome data under different treatment, (B) Numbers of DEGs in the transcriptome data of L. bicolor seedlings treated with $300 \mathrm{mM} \mathrm{NaCl}$ for $24 \mathrm{~h}$

The melatonin-induced increase in biomass was associated with enhanced photosynthesis. $\mathrm{NaCl}$ stress inhibited photosynthesis in L. bicolor seedlings [52], whereas pretreatment with melatonin significantly increased photosynthesis (Fig. 2), which is consistent with previous results in nonhalophytes [22, 45]. Photosynthesis is a key physiological process that is sensitive to salt stress [43]. Treatment of $L$. bicolor with $300 \mathrm{mM} \mathrm{NaCl}$ resulted in stomatal closure and thus a decrease in stomatal conductance, which also led to decreases in transpiration from the leaves, intercellular $\mathrm{CO}_{2}$ concentration, net photosynthetic rate and water use efficiency (Fig. 2). 
Table 1 Differentially expressed and highly transcribed genes related to genes related to photosynthesis and reactive oxygen species scavenging in the different treatment Limonium bicolor leaves

\begin{tabular}{|c|c|c|c|c|c|c|}
\hline Gene ID & B1 & B2 & FC & B3 & B4 & FC \\
\hline \multicolumn{7}{|c|}{ ADG1: Encodes the small subunit of ADP-glucose pyrophosphorylase. } \\
\hline Lb0G37377 & 612.33 & 732.32 & 0.26 up & 29.54 & 644.96 & 4.45 up \\
\hline \multicolumn{7}{|c|}{ DGD2: Encodes a UDP-galactose-dependent digalactosyldiacylglycerol (DGDG) synthase. } \\
\hline Lb1G03486 & 96.50 & 1.96 & -5.62 down & 2.91 & 82.79 & 4.83 up \\
\hline \multicolumn{7}{|c|}{ ATSUC4: Low affinity (10 mM) sucrose transporter in sieve elements (phloem). } \\
\hline Lb1G06992 & 4.05 & 65.24 & 4.01 up & 4.28 & 121.09 & 4.82 up \\
\hline Lb3G15617 & 24.60 & NS & NS & 2.46 & 52.38 & 4.41 up \\
\hline \multicolumn{7}{|c|}{ Phosphofructokinase family protein. } \\
\hline Lb6G30828 & 22.58 & 201.71 & 3.16 up & 20.99 & 361.12 & 4.10 up \\
\hline \multicolumn{7}{|c|}{ PNAD-MDH: Encodes a protein with NAD-dependent malate dehydrogenase activity. } \\
\hline Lb1G04420 & 826.21 & 843.68 & 0.03 up & 140.65 & 1082.78 & 2.94 up \\
\hline \multicolumn{7}{|c|}{ PSBA: Encodes chlorophyll binding protein D1. } \\
\hline Lb0G36726 & 52.91 & 48.85 & -0.12 down & 31.05 & 4660.16 & 7.23 up \\
\hline Lb4G25364 & 5.29 & 7.53 & 0.51 up & 10.30 & 1219.19 & 6.89 up \\
\hline Lb0G37372 & 77.23 & 82.87 & 0.10 up & 85.21 & 4367.29 & 5.68 up \\
\hline \multicolumn{7}{|c|}{ RRN165.2: Chloroplast-encoded 165 ribosomal RNA. } \\
\hline Lb0G37563 & 15.63 & 13.01 & -0.26 down & 10.34 & 1074.28 & 6.69 up \\
\hline Lb4G25504 & 12.09 & 16.79 & 0.47 up & 16.42 & 1754.74 & 6.74 up \\
\hline \multicolumn{7}{|c|}{ CRR42: Chloroplast NADH dehydrogenase assembly protein. } \\
\hline Lb3G18424 & 410.01 & 460.86 & 0.17 up & 11.66 & 172.86 & 3.89 up \\
\hline \multicolumn{7}{|c|}{ ATPA: Encodes the ATPase alpha subunit. } \\
\hline Lb4G23216 & 3.39 & 4.98 & 0.55 up & 2.21 & 231.44 & 6.71 up \\
\hline \multicolumn{7}{|c|}{ DALL5: Encodes a triacylglycerol lipase located in plastoglobuli. } \\
\hline Lb2G08239 & 3.00 & 39.17 & 3.70 up & 2.47 & 31.23 & 3.66 up \\
\hline \multicolumn{7}{|c|}{ RLK7: RLK7 belongs to a leucine-rich repeat class of receptor-likekinase (LRR-RLKs). } \\
\hline Lb4G23386 & 3.39 & 4.98 & 0.55 up & 2.21 & 231.44 & 6.71 up \\
\hline \multicolumn{7}{|c|}{ ABO8: Encodes ABO8, a pentatricopeptide repeat (PPR) protein. } \\
\hline Lb5G26864 & 26.36 & 57.19 & 1.12 up & 10.52 & 99.57 & 3.24 up \\
\hline \multicolumn{7}{|c|}{ NAD (P)-linked oxidoreductase superfamily protein. } \\
\hline Lb6G30054 & 26.36 & 57.19 & 1.12 up & 10.52 & 99.57 & 3.24 up \\
\hline \multicolumn{7}{|c|}{ ATGPX6: Encodes glutathione peroxidase. } \\
\hline Lb0G37493 & 298.78 & 536.27 & 0.84 up & 200.86 & 711.49 & 1.82 up \\
\hline \multicolumn{7}{|c|}{ HPCA1: Leucine rich receptor kinase. } \\
\hline Lb3G15760 & 399.21 & 115.54 & -1.79 down & 93.39 & 381.65 & 2.03 up \\
\hline \multicolumn{7}{|c|}{ DCC1: Encodes a putative thioredoxin DCC1. } \\
\hline Lb2G08796 & NS & NS & NS & $2.78 \mathrm{E}-17$ & 25.01 & 59.64 up \\
\hline \multicolumn{7}{|c|}{ AO: Role in the degradation of ascorbate to (mono) dehydroascorbate. } \\
\hline Lb1G05941 & NS & 88.01 & NS & 7.87 & 77.58 & 3.30 up \\
\hline \multicolumn{7}{|c|}{ MSRB1: 1-Cys methionine sulfoxide reductase. } \\
\hline Lb3G20002 & 26.25 & 24.76 & -0.08 down & 26.27 & 316.42 & 3.59 up \\
\hline \multicolumn{7}{|c|}{ MAD3: Encodes a 3-hydroxy-3-methylglutaryl coenzyme A reductase. } \\
\hline Lb3G18131 & 9.18 & 139.08 & 3.92 up & 9.18 & 67.49 & 2.88 up \\
\hline PRX17: Enco & lized class & & & & & \\
\hline Lb0G37582 & 10.60 & 72.48 & 2.77 up & 21.13 & 126.40 & 2.58 up \\
\hline DSPTP1E: En & Iosphatase & ר MPK12. & & & & \\
\hline Lb0G38281 & 9.09 & 124.93 & 3.78 up & 9.18 & 67.49 & 2.88 up \\
\hline FQR1: Encod & ucleotide- & -like quin & & & & \\
\hline Lb1G00304 & 1483.82 & 1629.17 & 0.13 up & 574.94 & 1387.82 & 1.27 up \\
\hline GH3.1: Encod & ar to IAA-a & & & & & \\
\hline Lb3G17391 & 38.75 & 35.25 & -0.14 down & 35.82 & 186.15 & 2.38 up \\
\hline PGP21: Enco & ansporter & oncentra & & & & \\
\hline Lb3G19218 & 33.44 & NS & NS & 89.32 & 319.35 & 1.84 up \\
\hline
\end{tabular}

Differentially expressed genes were filtered using the threshold of Informative/Non-Informative (I/NI) C 0.4 using the Dexus method. "FC (Fold change)" equals log 2 (B2-FPKM/ $\mathrm{B} 1-\mathrm{FPKM}$ or B4-FPKM/B3-FPKM), "up" represents up-regulated genes and "down" represents down-regulated genes. $\mathrm{B} 1,0 \mathrm{mM} \mathrm{NaCl}+0 \mu \mathrm{M}$ melatonin; $\mathrm{B} 2,0 \mathrm{mM} \mathrm{NaCl}+5 \mu \mathrm{M}$ melatonin; $\mathrm{B} 3,300 \mathrm{mM} \mathrm{NaCl}+0 \mu \mathrm{M}$ melatonin; $\mathrm{B} 1,300 \mathrm{mM} \mathrm{NaCl}+5 \mu \mathrm{M}$ melatonin 


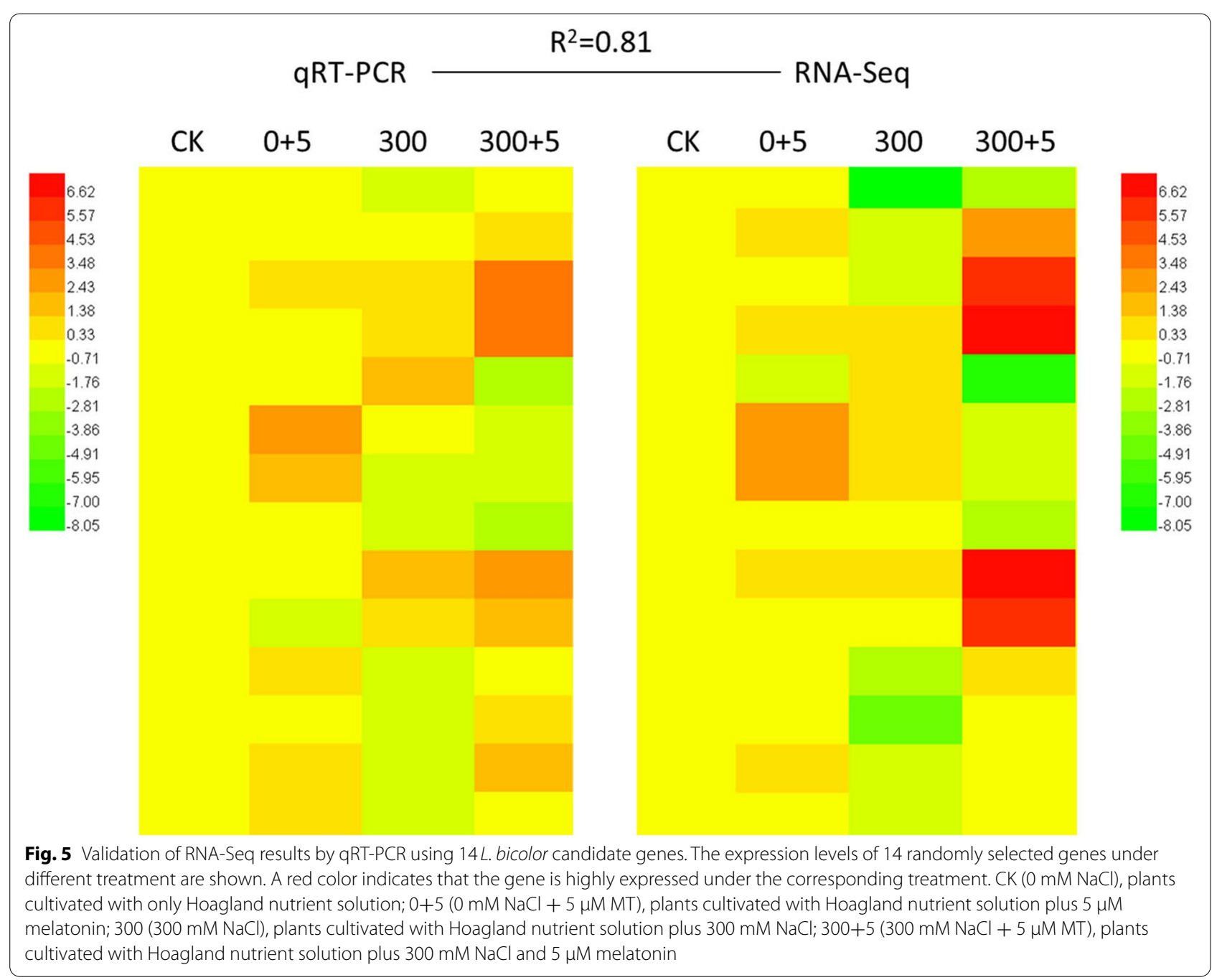

Exogenous melatonin application can promote stomatal opening and improve stomatal function (Fig. 2c), thereby increasing intercellular $\mathrm{CO}_{2}$ concentrations, water-use efficiency and improving net photosynthetic efficiency. This result is consistent with previous observations in watermelon ([22, 33]; Rahman et al. 2020). Although salt stress inhibited photosynthesis in L. bicolor seedlings, it led to significantly increased levels of chlorophyll in the leaves (Fig. 2a). This result showed that, at least for this species, salt stress inhibited photosynthesis not through a reduction of chlorophyll content but through stomatal factors [22]. Exogenous melatonin treatment increased photosynthesis in L. bicolor by improving stomatal function and enabling the plants to reopen their stomata under salt stress [46].

The osmotic stress associated with salt stress often causes dehydration and leads to ROS production [23, 51]. In addition, salt stress inhibits photosynthetic $\mathrm{CO}_{2}$ assimilation, which leads to the accumulation of excess light energy and the production of even more ROS [13]. ROS can cause serious oxidative damage to lipids, proteins, and nucleic acids, thereby damaging cells and disrupting plant metabolism [12]. Under salt stress, plants accumulate large amounts of ROS, such as peroxides, hydroxyl groups, and peroxy radicals, leading to oxidative stress, which in turn leads to increased levels of malondialdehyde (MDA), membrane dysfunction, and even cell death [21]. Consistent with these observations from other plants $[2,15,21]$, the amounts of $\mathrm{H}_{2} \mathrm{O}_{2}, \mathrm{O}_{2}{ }^{\cdot-}$, and MDA increased significantly in L. bicolor under salt stress (Fig. 3a, b). Exogenous melatonin treatment can reduce the contents of ROS (such as $\mathrm{H}_{2} \mathrm{O}_{2}$ and $\mathrm{O}_{2}{ }^{--}$) and MDA in salt-stressed L. bicolor. Melatonin is a well-known antioxidant that directly removes ROS and stabilizes the ROS concentration [4]. In addition, melatonin can increase antioxidant enzyme activity 


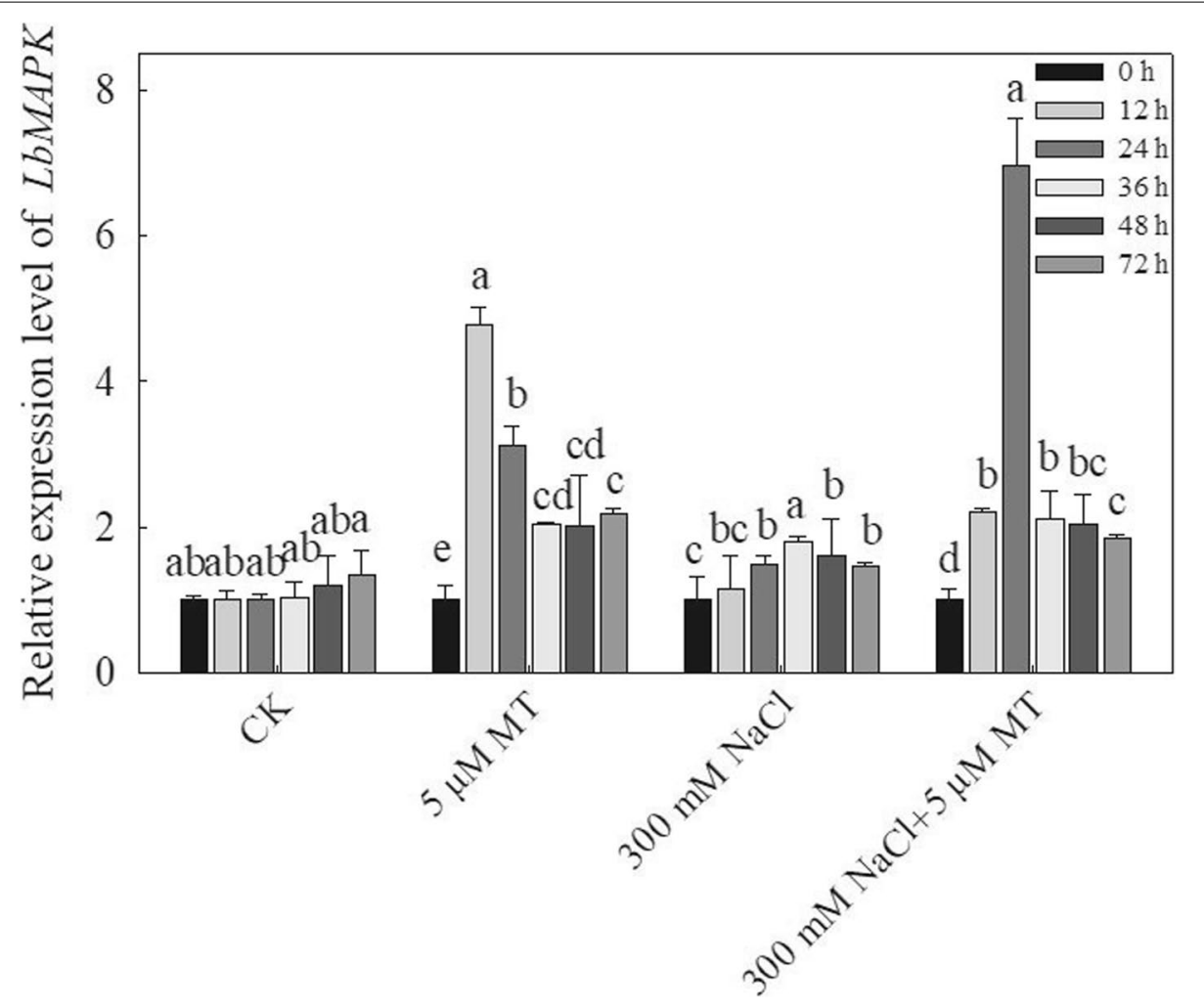

Fig. 6 Effects of melatonin ( $5 \mu \mathrm{M}$ ) on MAPK gene expression of L. bicolor leaves in six-week-old seedlings subjected to $300 \mathrm{mM} \mathrm{NaCl}$ for 0, 12, 24, 48 and $72 \mathrm{~h}$. Values are mean \pm standard deviation of three biological replicates. Bars labeled with different letters are significantly different at $P<0.05$ according to Duncan's multiple range tests. CK, $0 \mathrm{mM} \mathrm{NaCl}$

during oxidative stress [15]. Under salt stress, the activities of antioxidant enzymes (such as SOD, POD, CAT, and APX) in L. bicolor significantly increased after melatonin was exogenously applied (Fig. 3). The increased activities of these enzymes could remove excessive ROS and improve cellular redox homeostasis under salt stress $[44,45]$.

In eukaryotes, the MAPK signaling pathways play crucial roles in regulating plant responses to salt stress [30]. Studies showed that MAPK components can enhance salt stress tolerance by increased antioxidant enzyme activities $[29,55]$. In this study, melatonin can activate the MAPK signal cascade, regulate the expression of antioxidant enzyme genes, promote the activity of antioxidant enzymes, and ultimately enhance the tolerance of plants to abiotic stresses, which is consist to Xia et al. [48]. Salt stress increased the expression level of the MAPK gene in L. bicolor, and MAPK expression increased significantly after the application of exogenous melatonin (Fig. 6). Melatonin probably induced the MAPK cascade through the $\mathrm{H}_{2} \mathrm{O}_{2}$ pathway [47], which would further enhance the salt tolerance of $L$. bicolor seedlings. These results are consistent with previous results in naked oat (Avena nuda [14];).

In summary, transcriptome sequencing has been used to investigate the mechanism underlying melatonin alleviate $\mathrm{NaCl}$-induced growth inhibition by improving photosynthesis and increasing antioxidant enzyme activities. Exogenous melatonin can upregulate genes expression related to photosynthesis and reactive oxygen species scavenging, which can promote growth and alleviate oxidative stress caused by salt stress. Melatonin acts as a strong antioxidant that directly scavenges ROS and also removes ROS by enhancing other antioxidant enzyme activities [44]. Furthermore, melatonin treatment induces the expression of MAPKs, thereby regulating the expression of downstream stress-responsive genes and improving the salt tolerance of L. bicolor.

\section{Materials and methods}

\section{Plant materials and growth conditions}

L. bicolor seeds were kindly provided by Professor Xu Hualing, Dongying Academy of Agricultural Sciences, Shandong Province. The seeds were sterilized 
according to Li et al. [23] and then sown on wellwashed river sand in plastic pots $(16 \mathrm{~cm}$ in diameter), which were placed in a growth chamber with $600 \mu \mathrm{mol} \mathrm{m}^{-2} \mathrm{~s}^{-1}$ light (15-hday/9-h night photoperiod), a temperature of $25 \pm 3{ }^{\circ} \mathrm{C} / 22 \pm 3{ }^{\circ} \mathrm{C}$ (day/ night), and a relative humidity of $60 / 80 \%$ (day/night). After the leaves emerged, the plants were watered with Hoagland's nutrient solution.

\section{Combined $\mathrm{NaCl}$ and melatonin treatment}

When the seedlings reached the six-leaf stage (onemonth-old seedlings), they were subjected to $\mathrm{NaCl}$ and melatonin treatments. For the $\mathrm{NaCl}$ treatment, the seedlings were treated with Hoagland's nutrient solution containing $\mathrm{NaCl}$, which was increased by $50 \mathrm{mM}$ every $12 \mathrm{~h}$ to a final concentration of $300 \mathrm{mM}$ to avoid salt shock. The control seedlings were treated with Hoagland's nutrient solution only. To examine the effects of melatonin on $L$. bicolor seedlings, the $\mathrm{NaCl}$-treated and control seedlings were irrigated with 0 or $5 \mu \mathrm{M}$ melatonin dissolved in Hoagland's nutrient solution. The experiment for transcriptome included four treatments: (i) control (marked as: B1), L. bicolor plants cultivated with only Hoagland nutrient solution; (ii) melatonin (marked as: B2), Hoagland nutrient solution plus $0.5 \mu \mathrm{M}$ melatonin; (iii) $\mathrm{NaCl}$ stress (marked as: B3), Hoagland nutrient solution plus $300 \mathrm{mM} \mathrm{NaCl}$; (iv) $\mathrm{NaCl}$ stress with melatonin (marked as: B4) Hoagland nutrient solution plus $300 \mathrm{mM}$ $\mathrm{NaCl}$ and $0.5 \mu \mathrm{M}$ melatonin. The $L$. bicolor seedlings were treated with various combinations of salt and melatonin every $12 \mathrm{~h}$ for 15 consecutive days. Five replicates (3 plants per replicate) were used for each treatment. After 15 days, the leaves were collected to determine the biological indicators.

\section{Photosynthetic index, water use efficiency and chlorophyll content measurements}

After exposure to $\mathrm{NaCl}$ and melatonin treatment for 15 days, photosynthetic parameters were measured in fully expanded leaves using a $\mathrm{Li}-6000$ portable photosynthesis measurement system (LI-COR, Inc., Lincoln, NE, USA). The measurements were performed from 10:00 AM to 12:00 AM and five replicates were performed per treatment.

The parameters intrinsic water use efficiency (WUEint; ratio Pn/gs) and instantaneous water use efficiency (WUEins; ratio Pn/E) were calculated with $\mathrm{Pn}, \mathrm{g}_{\mathrm{s}}$ and $\mathrm{E}$ according to Rahman et al. [33].

After exposure to $\mathrm{NaCl}$ and melatonin treatment for 15 days, leaves $(0.3 \mathrm{~g}$ fresh weight) were quickly washed with $\mathrm{ddH}_{2} \mathrm{O}$ water and chlorophyll was extracted and measured according to the methods described by Liu et al. (2020). Briefly, leaves $(0.3 \mathrm{~g})$ were placed in a test tube with $5 \mathrm{~mL} 80 \%(\mathrm{v} / \mathrm{v})$ formaldehyde and dimethyl sulfoxide and then bathed at $65^{\circ} \mathrm{C}$ for $4 \mathrm{~h}$. After cooling and filtration through filter paper, the filtrate was topped up to $5 \mathrm{~mL}$ with $80 \%$ acetone. The chlorophyll content was calculated by measuring the absorbance at 663 and $645 \mathrm{~nm}$ using a UV spectrophotometer (UV756, Shanghai Youke Co., Ltd.) (Liu et al. 2020).

\section{Measurements of $\mathrm{H}_{2} \mathrm{O}_{2}, \mathrm{O}_{2}{ }^{--}$, and malondialdehyde}

The content of $\mathrm{H}_{2} \mathrm{O}_{2}$ and $\mathrm{O}_{2}{ }^{-{ }^{-}}$in detached leaves was determined using a UV spectrophotometer (UV756, Shanghai Youke Co., Ltd.). $\mathrm{H}_{2} \mathrm{O}_{2}$ and titanium sulfate (or titanium chloride) form a yellow precipitate of peroxide titanium complex, which can be dissolved by $\mathrm{H}_{2} \mathrm{SO}_{4}$ $(2 \mathrm{M})$ and determined by colorimetry at $415 \mathrm{~nm}$. The $\mathrm{O}_{2}{ }^{\cdot-}$ concentration was determined in plants by $\mathrm{O}_{2}{ }^{\cdot-}$ hydroxylamine oxidation [14]. According to the above principle, the standard curve is generated with a standard $\mathrm{H}_{2} \mathrm{O}_{2}$ and $\mathrm{O}_{2}{ }^{\cdot-}$ concentration gradient solution, and the regression curve between the $\mathrm{H}_{2} \mathrm{O}_{2}$ and $\mathrm{O}_{2}{ }^{-}$concentration and absorption value is obtained. The content of malondialdehyde (MDA) was measured according to Draper and Hadley [6] using the thiobarbituric acid method. Then, the same mass of plant tissue was ground with acetone and centrifuged at $1000 \mathrm{~g}$ and room temperature for $15 \mathrm{~min}$ to obtain the supernatant. The content of $\mathrm{H}_{2} \mathrm{O}_{2}$ and $\mathrm{O}_{2}{ }^{\cdot-}$ under different melatonin treatments was observed directly in leaves by DAB and NBT staining under salt stress.

\section{Antioxidant activity assays}

The activites of superoxide dismutase (SOD), catalase (CAT), peroxydase (POD), and ascorbate peroxidase (APX) were determined in the detached leaves of plants subjected to $\mathrm{NaCl}$ and melatonin treatments according to Li et al. [25].

\section{Transcriptome analysis}

High-quality RNA was extracted from the samples and validated for transcriptome analysis. The quality of RNA extracted from the samples was analyzed by agarose gel electrophoresis and then verified (the RNA concentration, RIN value, $28 \mathrm{~S} / 18 \mathrm{~S}$ and fragment size) using an Agilent 2100 Bio-analyzer (Agilent Technologies, Santa Clara, CA, United States). Then RNA purity (OD260/280) was detected using a ThermoFlyer NanoDrop UV spectrophotometer. The mRNA was isolated by Oligo-dT beads (Qiagen, Germany), and then randomly broken by adding the fragmentation buffer. Using random hexamers, first-strand cDNA was synthesized and then the second-strand cDNA using DNA polymerase I. The cDNA fragments were purified and enriched by PCR to construct the final RNA-Seq libraries. After the insert size of the libraries was checked and the 
concentrations quantified, the Illumina HiSeq platform was used for sequencing.

Raw RNA-Seq reads were filtered to remove adaptor sequences, repetitive sequences and low-quality reads (Quality value Phred $\leq 25$ bases, accounting for more than $40 \%$ of total reads) and obtain clean, effective and high-quality sequences (clean reads). Clean reads were spliced with Trinity, and the spliced transcript sequences were used as reference sequences. Then the clean reads were mapped to the L. bicolor genome sequence using Hisat2 software for similarity analysis and then the genes or transcripts can be annotated and quantified. The $p$-value obtained from the original hypothesis test was corrected. Transcripts with $P$. adj $<0.05$ and absolute $\log _{2}$ foldchange value $>1$ were considered to be significantly differentially expressed transcripts.

\section{qRT-PCR analysis}

The nucleotide sequences of $L$. bicolor genes were obtained from the RNA sequences [54]. Primers were designed using Beacon Designer (Premier Biosoft, Palo Alto, California, USA) (Supplementary Table 1) and used to clone the conserved region sequences (about $800 \mathrm{bp}$ ) of genes that have been verified. Real-time PCR was performed using AceQ Universal SYBR Green qPCR Master Mix (Vazyme Biotech, Nanjing, China) and a real-time quantitative PCR instrument (Bio-Rad Laboratories, Hercules, California, USA). The relative expression of each gene was calculated using the $2^{-\triangle \triangle \mathrm{Ct}}$ method [5, 14]. The housekeeping gene LbTUBULIN was used as an internal reference.

\section{Statistical analysis}

The statistical analysis was performed using the SPSS software package (version 19.0; IBM, Armonk, New York, USA). The statistical significance was determined using an analysis of variance (ANOVA), and significant differences $(P<0.05)$ between the values were determined using Duncan's multiple range test.

\section{Availability of data and materials}

The data sets supporting the results of this article are included within the article and its additional files. The RNA-Seq raw reads produced in this study have been deposited in the National Center for Biotechnology Information (NCBI) Sequence Read Archive (SRA) under BioProject accession PRJNA758442, which includes 12 SRAs (SRR15682774, SRR15682775, SRR15682776, SRR15682777, SRR15682778, SRR15682779, SRR15682780, SRR15682781, SRR15682782, SRR15682783, SRR15682784, SRR15682785).

\section{Supplementary Information}

The online version contains supplementary material available at https://doi. org/10.1186/s12870-021-03402-x.

Additional file 1: Table S1. The primers for genes used in real-time qPCR analysis.

Additional file 2: Fig. S1. The GO enriched functions of upregulated genes under melatonin $+300 \mathrm{mM} \mathrm{NaCl}$ treatment compared to these under $300 \mathrm{mM} \mathrm{NaCl}$ treatment.

\section{Acknowledgements}

We are grateful for Dr. Hongxia Zhang (College of Agriculture, Ludong University) for his critical comments on this work.

\section{Authors' contributions}

$M C$ and $B W$ designed the research, $J L, J L$ and $M Z$ performed the experiments, $J \mathrm{~L}$ wrote the paper with contributions from the other authors. JL, XU, KN analyzed the data. BW revised the paper. All authors read and approved the final manuscript.

\section{Funding}

This work was supported by Shandong Provincial "Bohai Granary" Science and Technology Demonstration Project (2019BHLC004), Shandong Province Natural Science Foundation (ZR2019MC065), Agricultural Variety Improvement Project of Shandong Province (2019LZGC009) and the Program for Scientific Research Innovation Team in Colleges and Universities of Shandong Province.

Availability of data and materials

Not applicable.

\section{Declarations}

Ethics approval and consent to participate

Not applicable.

Consent for publication

Not applicable.

Competing interests

The authors declare that they have no conflict of interest.

\section{Author details}

'Shandong Provincial Key Laboratory of Plant Stress Research, College of Life Sciences, Shandong Normal University, Jinan, Shandong 250014, People's Republic of China. ${ }^{2}$ DongYing Academy of Agricultural Sciences, Dongying, Shandong 257000, People's Republic of China.

Received: 31 July 2021 Accepted: 10 December 2021

Published online: 04 January 2022

References

1. Calvo JR, Gonzalez YC, Maldonado MD. The role of melatonin in the cells of the innate immunity: a review. J Pineal Res. 2013;55:103-20.

2. Cen H, Wang T, Liu H, Tian D, Zhang Y. Melatonin application improves salt tolerance of alfalfa (Medicago sativa L.) by enhancing antioxidant capacity. Plants (Basel). 2020;9(2):220.

3. Chen Q, Qi WB, Reiter RJ, Wei W, Wang BM. Exogenously applied melatonin stimulates root growth and raises endogenous indoleacetic acid in roots of etiolated seedlings of Brassica juncea. J Plant Physiol. 2009;166:324-8.

4. Choi S, Dadakhujaev S, Ryu H, Kim T, Kim EK. Melatonin protects against oxidative stress in granular corneal dystrophy type 2 corneal fibroblasts by mechanisms that involve membrane melatonin receptors. J Pineal Res. 2011;51:94-103. 
5. Ding F, Chen M, Sui N, Wang BS. $\mathrm{Ca}^{2+}$ significantly enhanced development and salt-secretion rate of salt glands of Limonium bicolor under $\mathrm{NaCl}$ treatment. S Afr J Bot. 2010;76:95-101.

6. Draper HH, Hadley M. Malondialdehyde determination as index of lipid peroxidation. Methods Enzymol. 1990;186:421-31.

7. Duan HM, Ma YC, Liu RR, Li Q, Yang Y, Song J. Effect of combined waterlogging and salinity stresses on euhalophyte Suaeda glauca. Plant Physiol Biochem. 2018;127:231-7.

8. Feng ZT, Deng YQ, Fan $\mathrm{H}$, Sun QJ, Sui N, Wang BS. Effects of $\mathrm{NaCl}$ stress on the growth and photosynthetic characteristics of UImus pumila. $\mathrm{L}$ seedlings in sand culture Photosynthetica. 2014b;52:313-20.

9. Feng ZT, Deng YQ, Zhang SC, Liang $X$, Yuan F, Hao JL, et al. $\mathrm{K}(+)$ accumulation in the cytoplasm and nucleus of the salt gland cells of Limonium bicolor accompanies increased rates of salt secretion under $\mathrm{NaCl}$ treatment using NanoSIMS. Plant Sci. 2015;238:286-96.

10. Feng ZT, Sun QJ, Deng YQ, Sun SF, Zhang JG, Wang BS. Study on pathway and characteristics of ion secretion of salt glands of Limonium bicolor. Acta Physiol Plant. 2014a;36:2729-41.

11. Flowers TJ, Colmer TD. Salinity tolerance in halophytes. New Phytol. 2008;179:945-63.

12. Foyer C, Noctor G. Oxygen processing in photosynthesis: regulation and signalling. New Phytol. 2000;146:359-88.

13. Foyer $\mathrm{CH}$. Reactive oxygen species, oxidative signaling and the regulation of photosynthesis. Environ Exp Bot. 2018;154:134-42.

14. Gao W, Zhang Y, Feng Z, Bai Q, He J, Wang Y. Effects of melatonin on antioxidant capacity in naked oat seedlings under drought stress. Molecules. 2018;23(7):1580.

15. Gong B, Yan Y, Wen D, Shi Q. Hydrogen peroxide produced by NADPH oxidase:a novel downstream signaling pathway in melatonin-induced stress toelrance in Solanum lycopersicum. Physiol Plant. 2017;160:396-409.

16. Guo J, Suo S, Wang BS. Sodium chloride improves seed vigour of the euhalophyte Suaeda salsa. Seed Sci Res. 2015;25:335-44.

17. Guo JR, Li YD, Han G, Song J, Wang BS. NaCl markedly improved the reproductive capacity of the euhalophyte Suaeda salsa. Funct Plant Biol. 2018a;45:350-61.

18. Guo YY, Tian SS, Liu SS, Wang WQ, Sui N. Energy dissipation and antioxidant enzyme system protect photosystem II of sweet sorghum under drought stress. Photosynthetica. 2018b;56:861-72.

19. Han N, Lan W, He X, Shao Q, Wang BS. Expression of a Suaeda salsa, vacuolar $\mathrm{H}^{+} / \mathrm{Ca}^{2+}$, transporter gene in arabidopsis, contributes to physiological changes in salinity. Plant Mol Biol Rep. 2011;30:470-7.

20. Hardeand R, Madrid JA, Tan DX, Reiter RJ. Melatonin, the circadian multioscillator system and health: the need for detailed analyses of peripheral melatonin signaling. J Pineal Res. 2012;34:233-41.

21. Lee $\mathrm{DH}$, Kim YS, Lee CB. The inductive responses of the antioxidant enzymes by salt stress in the rice (Oryza sativa L.). J Plant Physiol. 2001;158:737-45.

22. Li H, Chang J, He C, Wang Z, Gu X, Wei C, et al. Exogenous melatonin confers salt stress tolerance to watermelon by improving photosynthesis and redox homeostasis. Front. Plant Sci. 2017:8:295.

23. Li J, Liu J, Zhu T, Zhao C, Li L, Chen M. The role of melatonin in salt stress responses. Int J Mol Sci. 2019;20(7):1735.

24. Li J, Yuan F, Liu Y, Zhang M, Liu Y, Zhao Y, et al. Exogenous melatonin enhances salt secretion from salt glands by upregulating the expression of ion transporter and vesicle transport genes in Limonium bicolor. BMC Plant Biol. 2020;20:493.

25. LiT, Liu RJ, He XH, Wang BS. Enhancement of superoxide dismutase and catalase activities and salt tolerance of euhalophyte Suaeda salsa L. by mycorrhizal fungus glomus mosseae. Pedosphere. 2012;22:217-24.

26. Lin J, Li JP, Yuan F, Yang Z, Wang BS, Chen M. Transcriptome profiling of genes involved in photosynthesis in Elaeagnus angustifolia L. under salt stress. Photosynthetica. 2018:56:998-1009.

27. Liu DD, Sun XS, Liu L, Shi HD, Chen SY, Zhao DK. Overexpression of the melatonin synthesis-related gene S/COMT1 improves the resistance of tomato to salt stress. Molecules. 2019;24(8):1514.

28. Liu SS, Wang WQ, Li M, Wan SB, Sui N. Antioxidants and unsaturated fatty acids are involved in salt tolerance in peanut. Acta Physiol Plant. 2017;39(9):207.

29. Miransari M, Rangbar B, Khajeh K, Tehranchi MM, Rusta Azad R, Nagafi F, Rahnemaie R. Salt stress in plants. 2013; ISBN: 978-1-4614-6107-4. Chapter 7, salt stress and MAPK signaling in plants.
30. Pathak RK, Taj G, Pandey D, Arora S, Kumar A. Modeling of the MAPK machinery activation in response to various abiotic and biotic stresses in plants by a system biology approach. Bioinformation. 2013;9:443-9.

31. Rahman M, Mostofa MG, Keya SS, Rahman A, Das AK, Islam R, et al. Acetic acid improves drought acclimation in soybean: an integrative response of photosynthesis, osmoregulation, mineral uptake and antioxidant defense. Physiol Plant. 2021a;172(2):334-50.

32. Rahman MM, Mostofa MG, Keya SS, Siddiqui MN, Ansary MMU, Das AK, et al. Adaptive mechanisms of halophytes and their potential in improving salinity tolerance in plants. Int J Mol Sci. 2021b;22:10733.

33. Rahman MM, Mostofa MG, Rahman MA, Islam MR, Keya SS, Das AK, et al. Acetic acid: a cost-effective agent for mitigation of seawater-induced salt toxicity in mung bean. Sci Rep. 2019;23;9(1):15186.

34. Rodriguez C, Mayo JC, Sainz RM, Antolin I, Herrera F, Martin V, et al. Regulation of antioxidant enzymes: a significant role for melatonin. J Pineal Res. 2004;36:1-9.

35. Roncarati F, Rijstenbil JW, Pistocchi R. Photosynthetic performance, oxidative damage and antioxidants in Cylindrotheca closterium in response to high irradiance. UVB radiation and salinity Mar Biol. 2008;153:965-73.

36. Rozema J, Riphagen I. Physiology and ecologic relevance of salt secretion by the salt gland of Glaux maritima L. Oecologia. 1977;29(4):349-57.

37. Ruiz-Lozano JM, Porcel R, Azcon R, Aroca R. Regulation by arbuscular mycorrhizae of the integrated physiological response to salinity in plants: new challenges in physiological and molecular studies. J Exp Bot. 2012;63:4033-44.

38. Shao Q, Han N, Ding T, Zhou F, Wang BS. SsHKT1,1 is a potassium transporter of the C3 halophyte Suaeda salsa that is involved in salt tolerance. Funct Plant Biol. 2014;41:790-802.

39. Song J, Wang BS. Using euhalophytes to understand salt tolerance and to develop saline agriculture: Suaeda salsa as a promising model. Ann Bot. 2015:115:541-53.

40. Sreenivasulu N, Grimm B, Wobus U, Weschke W. Differential response of antioxidant compounds to salinity stress in salt-tolerant and salt-sensitive seedlings of fox-tail millet (Setariaitalica). Physiol Plant. 2000;109:435-42.

41. Sui N, Han GL. Salt-induced photoinhibition of PSIII is alleviated in halophyte Thellungiella halophila, by increases of unsaturated fatty acids in membrane lipids. Acta Physiol Plant. 2014;36:983-92.

42. Sun S, Wen D, Yang W, Meng Q, Shi Q, Gong B. Overexpression of caffeic acid O-methyltransferase 1 (COMT1) increases melatonin level and salt stress tolerance in tomato plant. J Plant Growth Regul. 2019:1-15.

43. Takahashi S, Murata N. How do environmental stresses accelerate photo inhibition? Trends Plant Sci. 2008:13:178-82.

44. Tan DX, Reiter RJ, Manchester LC, Yan M, El-Sawi M, Sainz RM, et al. Chemical and physical properties and potential mechanisms: melatonin as a broad spectrum antioxidant and free radical scavenger. Curr Top Med Chem. 2002:2:181-97.

45. Wang LY, Liu JL, Wang WX, Sun Y. Exogenous melatonin improves growth and photosynthetic capacity of cucumber under salinity-induced stress. Photosynthetica. 2016;54(1):19-27.

46. Wang P, Yin L, Liang D, Li C, Ma F, Yue Z. Delayed senescence of apple leaves by exogenous melatonin treatment: toward regulating the ascorbate-glutathione cycle. J Pineal Res. 2012;53:11-20.

47. Wen D, Gong B, Sun S, Liu S, Wang X, Yang F, et al. Promoting roles of melatonin in adventitious root development of Solanum lycopersicum L. by regulating auxin and nitric oxide signaling. Front. Plant Sci. 2016;7:718

48. Xia XJ, Wang YJ, Zhou YH, Tao Y, Mao WH, Shi K, et al. Reactive oxygenspecies are involved in brassinosteroids-induced stress tolerance in cucumber. Plant Physiol. 2009;150:801-14.

49. Xu Y, Liu R, Sui N, Shi WW, Wang L, Tian CY, et al. Changes in endogenous hormones and seed-coat phenolics during seed storage of two Suaeda salsa populations. Aust J Bot. 2016:4:325-32.

50. Yan Y, Jing X, Tang H, Li X, Gong B, Shi Q. Using transcriptome to discover a novel melatonin-induced sodic alkaline stress resistant pathway in Solanum lycopersicum L. Plant Cell Physiol. 2019;60:2051-64.

51. Yang Z, Wang $Y$, Wei $X$, Zhao X, Wang B. Transcription profiles of genes related to hormonal regulations under salt stress in sweet sorghum. Plant Mol Biol Rep. 2017;35:1-14.

52. Yuan F, Liang X, Li Y, Yin S, Wang B. Methyl jasmonate improves tolerance to high salt stress in the recretohalophyte Limonium bicolor. Funct Plant Biol. 2019;46:82-92 
53. Yuan F, Lyu MJ, Leng BY, Zheng GY, Feng ZT, Li PH, et al. Comparative transcriptome analysis of developmental stages of the Limonium bicolor leaf generates insights into salt gland differentiation. Plant Cell Environ. 2015;38:1637-57.

54. Yuan F, Lyu MJA, Leng BY, Zhu XG, Wang BS. The transcriptome of $\mathrm{NaCl}$ treated Limonium bicolor, leaves reveal the genes controlling salt secretion of salt gland. Plant Mol Biol. 2016;91:241-56.

55. Zaidi I, Ebel C, Belgaroui N, Ghorbel M, Amara I, Hanin M. The wheat MAP kinase phosphatase 1 alleviates salt stress and increases antioxidant activities in Arabidopsis. J Plant Physiol. 2016;193:12-21.

56. Zhang N, Zhang HJ, Zhao B, Sun QQ, Cao YY, Li R, et al. The RNA-seq approach to discriminate gene expression profiles in response to melatonin on cucumber lateral root formation. J Pineal Res. 2014;56:39-50.

57. Zhu Y, Guo MJ, Song JB, Zhang SY, Guo R, Hou DR, et al. Roles of endogenous melatonin in resistance to Botrytis cinerea infection in an Arabidopsis model. Front Plant Sci. 2021;12:683228.

\section{Publisher's Note}

Springer Nature remains neutral with regard to jurisdictional claims in published maps and institutional affiliations.

- fast, convenient online submission

- thorough peer review by experienced researchers in your field

- rapid publication on acceptance

- support for research data, including large and complex data types

- gold Open Access which fosters wider collaboration and increased citations

- maximum visibility for your research: over 100M website views per year

At BMC, research is always in progress.

Learn more biomedcentral.com/submissions 